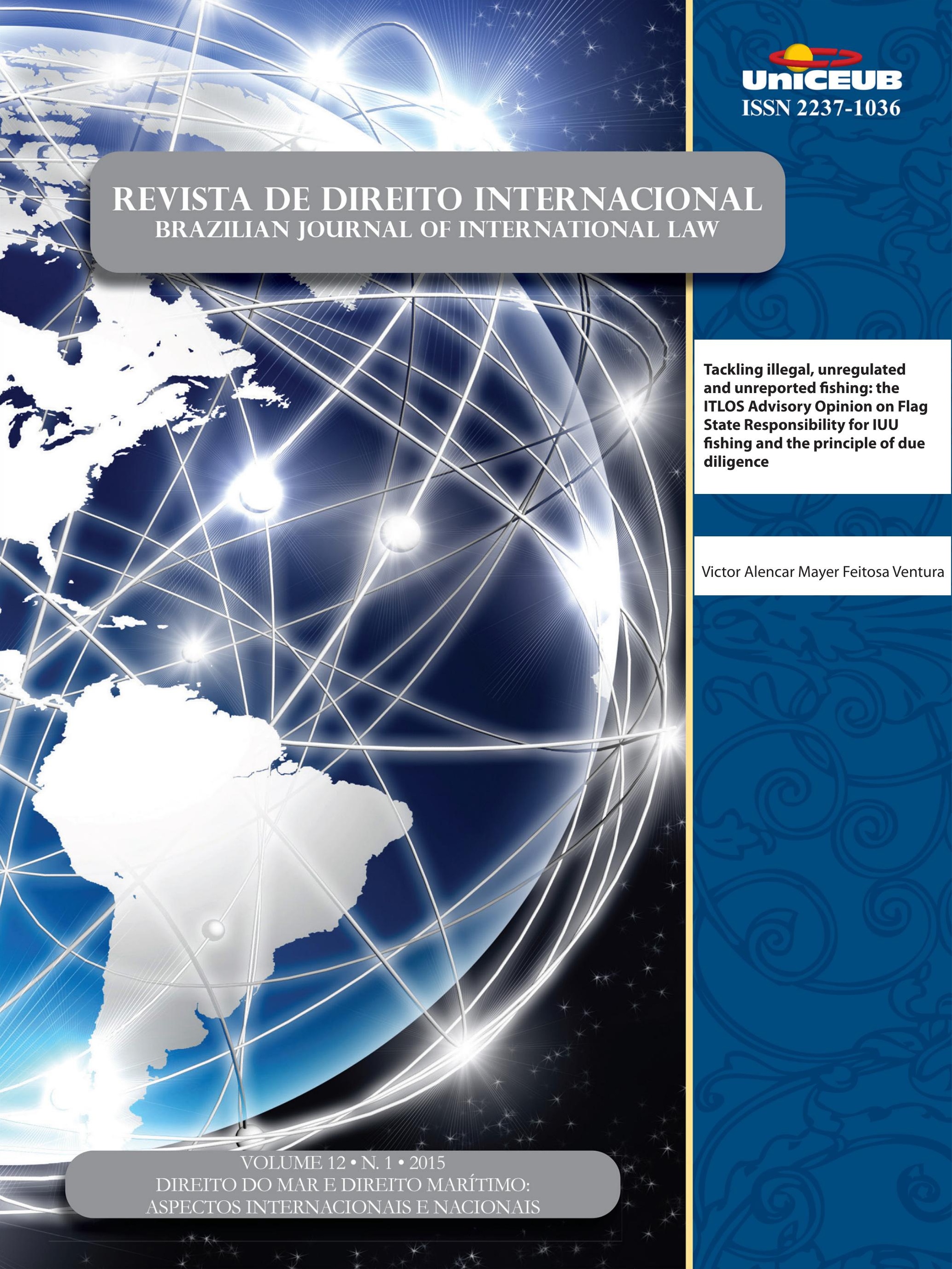




\section{Sumário}

\section{Crônicas}

CRôNICAS DA ATUALIDADE do DiREITO INTERNACIONAL ........................................................ 2

Nitish Monebhurrun (org.)

Towards a european regulation of the importation of conflict minerals?..... 2

Nitish Monebhurrun

Keeping up with the terrorists: the EU's proposed Passenger Name Records (PNR) Directive \& european security

Eshan Dauhoo

A histórica reaproximação de Cuba e EUA

Erika Braga

A contextualização da atual reivindicação da Grécia para receber indenizações por atos da Alemanha durante a Segunda Guerra Mundial . .10

Natália da Silva Gonçalves

José Eduardo Paiva Miranda de Siqueira

Crônicas da jurisprudência do Direito Internacional (CIJ/ITLOS): Decisões da Corte Internacional de Justiça e do Tribunal Internacional Sobre o Direito do Mar .14

Nitish Monebhurrun (Org.)

Corte Internacional de Justiça

Estudo da decisão da Corte Internacional de Justiça no caso Croácia v. Servia (03/02/2015) .14

Liziane Paixão Silva Oliveira e Maria Edelvacy Marinho

Questões relacionadas com a apreensão e detenção de certos documentos e dados: (Timor Leste c. Austrália) - O reconhecimento do retorno de uma relação amigável entre Timor-Leste e Austrália e a nova decisão da CIJ, 6 de maio de 2015 . 20

Gleisse Ribeiro Alves

Tribunal Internacional sobre Direito do Mar

Caso da delimitação da fronteira marítima entre o Gana e a Costa do Marfim no Oceano Atlântico: medidas cautelares $(25 / 04 / 2015)$

Nitish Monebhurrun

Comentário à Opinião Consultiva 21 do Tribunal Internacional para o Direito Do Mar [02/04/2015] (Responsabilidade do Estado de Bandeira pela pesca ilícita, não declarada ou não regulamentada) ...............25

Carina Costa de Oliveira 
CRÔNICAS DO DIREITO INTERNACIONAL DOS INVESTIMENTOS

Nitish Monebhurrun (Org.)

A inclusão da responsabilidade social das empresas nos novos Acordos de Cooperação e de Facilitação dos Investimentos do Brasil: uma revolução 33

Nitish Monebhurrun

\section{O Direito do Mar Perante as JuRisdições INTERnacionais}

CoAstal States' Rights IN THE MARITIME AREAS UNDER UNCLOS .40 Tullio Treves

TACKling illegal, unregulated And unReported Fishing: THE ITLOS Advisory OpINION on Flag State Responsibility for IUU fishing AND THE PRINCiple of DUE DiligenCE ...50 Victor Alencar Mayer Feitosa Ventura

REFLEXões PROVENIENTES do DisSENSO: UMA ANÁLISE CRÍtica A RESPEITO do CASO Austrália versus Japão Perante a Corte InTERnacional de JustiçA .......................................68 Luciana Ferna ndes Coelho

Os TRATADOS INTERNACIONAIS DE DIREITO DO MAR E SEUS EFEITOS SOBRE TERCEIROS ESTADOS ..... 86 Tiago V. Zanella

\section{InStRumentos JURÍdicos PARA A GeStÃo do MAR}

OS LIMITES DOS TERMOS BEM PÚBLICO MUNDIAL, PATRIMÔNIO COMUM DA HUMANIDADE E BENS COMUNS PARA DELIMITAR AS OBRIGAÇÕES DE PRESERVAÇÃO DOS RECURSOS MARINHOS 109 Carina Costa de Oliveira e Sandrine Maljean-Dubois

Os limites do PLANEJAMENTO DA OCUPAÇÃo SUSTENTÁVEL DA ZONA COSTEIRA BRASILEIRA ... 126 Carina Costa de Oliveira e Luciana Coelho

CORRENDO PARA O MAR NO ANTROPOCENO: A COMPLEXIDADE DA GOVERNANÇA DOS OCEANOS E A ESTRATÉGIA BRASILEIRA DE GESTÃO DOS RECURSOS MARINHOS 
A comissão de limites da Plataforma continental (CLPC) E Os DESAFios Na delineaÇÃo DAS PLATAFORMAS CONTINENTAIS ESTENDIDAS................................................... 170

Alexandre Pereira da Silva

\section{A PROTEÇÃo DO MEIO AMBIENTE MARINHO}

O gRANDE JOGo do ÁrTiCo: REFLEXões COM BASE NA PERSPECTIVA DE EXPLORAÇão ECONÔMICA

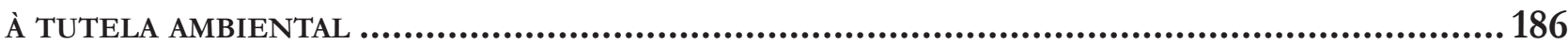

Fernando Rei e Valeria Cristina Farias

Instrumentos Públicos e Privados para a reparação do dano ambiental causado por DERRAMAMENTO DE ÓLEO NO MAR SEM ORIGEM DEFINIDA: AS MANCHAS ÓRFÃS

Renata Brockelt Giacomitti e Katya R. Isaguirre-Torres

O DIREITO INTERNACIONAL PRIVADO E A RESPONSABILIDADE CIVIL EXTRACONTRATUAL POR DANOS AMBIENTAIS CAUSADOS POR TRANSPORTES MARÍTIMOS À LUZ DO DIREITO BRASILEIRO ....... 217 Inez Lopes

A NECESSIDADE DE REPENSAR OS MECANISMOS DE RESPONSABILIDADE AMBIENTAL EM CASO DE riscos de VAZamento de PETRóleo Na Zona Econômica Exclusiva do BrasiL

Marcelo D. Varella

\section{Problemáticas do Direito Marítimo}

A FisCALIZAÇão SANitÁRIA DAS EMBARCAÇÕES EM ÁGUAS JURISDICIONAIS BRASILEIRAS: NOTAS aCERCA da (IN)efetividade da Súmula 50 da AGU

Joedson de Souza Delgado e Ana Paula Henriques da Silva

A IMO E A REPRESSÃo AO ROUBO ARMADO CONTRA NAVIOS: DA RETÓRICA INTERNACIONAL À COOPERAÇÃO REGIONAL

André Panno Beirão e Charles Pacheco Piñon

\section{O Direito do Mar diante da Pirataria}

O DIREITO INTERNACIONAL EM FACE DA PIRATARIA EM ALTO-MAR: UMA PERSPECTIVA CRÍTICA.289 Maiquel Ângelo Dezordi Wermuth e Rafaela Correa 
Pirataria marítima: A EXPERIÊnCIA Somália

Eduardo Augusto S. da C. Schneider

\section{Temas Gerais}

DRAWING THE LINE: ADDRESSING ALLEGATIONS OF UNCLEAN HANDS IN INVESTMENT ARBITRATION*

Mariano de Alba

Para Que Serve a história do Direito internacional?

George Rodrigo Bandeira Galindo

As interferências entre a Política Externa e de Segurança Comum Europeia (Pesc) e O DiREITO DAS NaÇões UNIDAS

Leonardo de Camargo Subtil

Introdução Às regras de aplicaÇão da Convenção da ONU Sobre Contratos de ComPRA E VENDA INTERNACIONAL DE MERCADORIAS E O DIREITO INTERNACIONAL PRIVADO BRASI-

LEIRO 380

Paul Hugo Weberbauer e Eugênia Cristina Nilsen Ribeiro Barza

A REgulaÇÃo das EMPRESAS TRANSNACIONAIS ENTRE AS ORDENS JURÍDICAS ESTATAIS E NÃO ESTATAIS.

Mateus de Oliveira Fornasier e Luciano Vaz Ferreira

OUtLAWING HATE SPEECH IN DEMOCRATIC STATES: THE CASE AGAINST THE INHERENT LimitAtions doctrine concerning Article 10 (1) of the European Convention on Human

Rights 416

Stefan Kirchner 


\title{
Tackling illegal, unregulated and unreported fishing: the ITLOS Advisory Opinion on Flag State Responsibility for IUU fishing and the principle of due diligence*
}

Victor Alencar Mayer Feitosa Ventura**

\begin{abstract}
One of the major challenges of the International Law of the Sea (LOS) is the overexploitation of fisheries worldwide. According to recent data, approximately $75 \%$ of the world's fisheries are either over or fully exploited, mainly due to illegal, unregulated and unreported (IUU) fishing. In order to tackle IUU fishing, a wide historical comprehension of the problem is provided in this paper, together with an investigation on the emergence of a new and integrated approach to the issue of IUU fishing. For that, the Advisory Opinion on flag state responsibility rendered by the International Tribunal for the Law of the Sea (ITLOS) of April 2015 is herein analyzed. Based on primary international sources, such as the United Nations Convention for the Law of the Sea (UNCLOS), and on specific case law, this paper aims at pinpointing the relevant role of the Tribunal in setting higher protective parameters for fisheries within the LOS. In an effort to overcome traditional approaches, the Tribunal is encrusting the environmental principle of "due diligence" in its decisions and, therefore, contributing to a fructiferous interaction between the LOS and international environmental law. Finally, the article also notes that the international society still needs to undertake reform and implementation efforts, if illegal fishing is to be overcome.
\end{abstract}

Key-words: International Law of the Sea. Illegal fishing. Integrated approach. ITLOS. Due diligence.

\section{INTRODUCTION}

In an effort to raise attention towards the need for a renewed approach to the protection of the seas, Davor Vidas and Peter Schei refer continuously to the "world ocean", a term that, according to both authors, considers seas and oceans as forming an integrated unit. ${ }^{1}$ This view is part of a greater scholarly effort to tackle traditional and isolated approaches within the Law of the Sea (LOS).

For centuries, states have been stuck to the opposing doctrines of the freedom of the seas, on the one side, and the sovereignty rights over natural resources, on the other, in a clash that has produced multiples victims: the ocean, its fauna and flora, as well as the human population that depend on the seas to survive. That approach is known as "zonal", as it divides the

** $\mathrm{PhD}$ Researcher in International Law of the Sea at the University of Hamburg. LL.M. at the Federal University of Paraíba (UFPB). Email:vfventura@gmail.com

1 VIDAS, Davor; SCHEI, Peter Johan (Ed.). The world ocean in globalization: climate change, sustainable fisheries, biodiversity, shipping regional issues. Leiden: Nijhoff, 2011. p. 2. 
seas into zones that belong either to the coastal state, or to no one. A sort of myopic fashion to glance at the world ocean that often reinforces ancient conceptions and impedes a thorough protection of the marine environment.

The zonal approach does not take into account the need for an integrated marine management, based on ecosystem considerations, without which the protection of the oceanic environment rests too difficult to be achieved. One of the major challenges of the LOS and this renewed, integrated approach is the grave issue of illegal, unreported and unregulated fishing in the seas. IUU fishing consists of a broad concept that encompasses numerous wrongful and illicit fishing capture activities. According to a definition set forward by the International Plan of Action to Prevent, Deter and Eliminate IUU fishing (IPOA-IUU), of the Food and Agriculture Organization of the United Nations (FAO), those three key terms of the concept are designed to encompass numerous wrongful and illicit fishing capture activities. Thus, "illegal" fishing is the one conducted in violation of national laws or international obligations, whereas "unreported" fishing refers to activities which "have not been reported, or have been misreported, to the relevant national authority (or to a regional fisheries management organization), in contravention of national laws and regulations". Finally, fishing activities are "unregulated" when they occur in areas where no regulatory systems exist, or in a manner that is inconsistent with the conservation and management measures of a coastal state or a regional fisheries organization. ${ }^{2}$

The problem is even more serious if one take into account the fact that fisheries around the world are source not only of health, but also of wealth. ${ }^{3}$ They are absolutely relevant to the economy and well-being of coastal communities, providing food security, job prospects, income and livelihoods as well as enabling cultural identity. Besides, fish is an in-

2 In line with the IPOA definition for IUU fishing, it ought to be noted that despite the controversial nature of "unregulated" fishing, the IPOA "is generally concerned with unregulated fishing that is likely to frustrate the achievement of sustainable fisheries". See: UNITED NATIONS. International Plan of Action to Prevent, Deter and Eliminate IUU Fishing. FAO, Committee on Fisheries, Rome, 2001. Available at: <http://www.fao.org/docrep/003/y1224e/y1224e00. htm>. Access on: 23 May 2015.

3 In his foreword to the 2014 FAO Report on "The state of world fisheries and aquaculture", José Graziano da Silva highlights the relevance of fisheries to the poorest countries, to which fish is "sometimes worth half of the total value of their traded commodities". dispensable source of protein, especially to the world's poorest countries. According to a detailed report by the FAO, approximately 158 million tons of fish landed in ports worldwide in 2012, directly employing millions of people in fishing operations. ${ }^{4}$ Besides, approximately 90 percent of all fish stocks are captured within 200 miles of shore, the traditional limit of the Exclusive Economic Zone (EEZ), ${ }^{5}$ and therefore under coastal states resources sovereignty. ${ }^{6}$ The remaining 10 percent are considered straddling stocks, or fish stock "which occurs both within the EEZ and in an area beyond or adjacent to EEZ", meaning the high seas or a neighboring economic zone. ${ }^{7}$

Nonetheless, global efforts to sustainably manage fisheries, in order to allow for the continued flow of trade, are undermined by IUU fishing. In extreme circumstances, illegal fishing can lead to the semi-collapse of fish stocks - such as those of the Patagonian toothfish during the 1990 's $-{ }^{8}$ or seriously impair efforts to rebuild depleted stocks, what makes it a grave problem in an ongoing industrial scale. In fact, pirate fishing jeopardizes regular and documented fishing operators, disturbs ecosystems, and affects fish-dependent populations throughout the globe. ${ }^{9}$

4 According to the 2014 FAO Report, those "landings" consist both of captured fish in the seas and fish bred and harvested within fish "farms", also known as aquaculture. Despite a stable amount of landings per capture (around 90 million tons yearly), global fish production has grown steadily due to increased investments in aquaculture and in more efficient distribution channels. In 2012, aquaculture alone was responsible for approximately 67 million tons of landings worldwide, i.e. almost $42 \%$ of the world's landings. See: UNITED NATIONS. The state of the world fisheries and aquaculture. FAO Fisheries and Aquaculture Department, FAO, Rome, 2014. p. 4.

5 The EEZ is one of the maritime zones established by the UNCLOS (arts. 55 to 75), which stretches up to 200 nautical miles, encompassing the territorial sea and the contiguous zone of the coastal state. Bordering the EEZ are the high seas and other adjacent national economic zones.

6 KRASKA, James. The lost dimension: food security and the South China Sea disputes. Harvard Law School National Security Journal, Online article, 2015. Availlable at: <http://harvardnsj. org/2015/02/the-lost-dimension-food-security-and-the-south-china-sea-disputes/>. Access on: 29 Apr. 2015.

7 The definition of "straddling stock" is provided by the FAO on-line glossary, and stems from article 63(2) of UNCLOS. Available at: <http://www.fao.org/faoterm/en/?defaultCollId=21>. Visited on: 21 May. 2015.

8 See: Coalition of Legal Toothfish Operators Inc. Available at: <http://www.colto.org/toothfish/>. Visited on: 22 May. 2015.

9 On the issue of overfishing in Brazilian waters, as well as on management strategies adopted to tackle this problem, see: BARROS-PLATIAU, Ana Flávia et al. Correndo para o mar no antropoceno: a complexidade da governança dos oceanos e a estratégia 
According to latest statistics published by FAO, the current global stock status reflects the following picture: 57 percent were estimated to be fully exploited, 30 percent were overexploited, and 13 percent non-fully exploited in 2012. Fisheries are non-fully exploited when the majority of the stocks is "moderately exploited", fully exploited when it is already at or very close to producing their "maximum sustainable yield", and overexploited when it is either depleted or exhausted. ${ }^{10}$ One could infer that the overexploitation herein depicted is one of the reasons why fish production per capture has stabilized, instead of sustainably increased.

The main international legal documents at hand to attack this problem are the third United Nations Convention on the Law of the Sea (UNCLOS), the 1995 United Nations Fish Stocks Agreement (UNFSA) and the FAO Code of Conduct for Responsible Fisheries (FAO, 1995), which will be later analyzed in this article. They are all unisonous in requiring the maintenance or restoration of fish stocks at levels that are capable of producing their "maximum sustainable yield" (MSY), i.e. the largest amount of fish catches that allows for the natural reproduction of stocks.

Illegally induced overfishing is a problem with a multidimensional nature, given economic, social, political, technological and legal aspects constantly interacting in defining the current status of global fisheries. For the purposes of this paper, exclusively the legal nature will be scrutinized, with special regard to the need to implement an integrated approach to the management of global fisheries, based on state of the art literature on the topic. With this goal, to comprehend the historic background of the LOS concerning the protection of living resources is paramount in assessing the most effective strategies to tackle IUU fishing.

Finally, this article aims at analyzing the Advisory Opinion on flag state responsibility for Illegal, Unregulated and Unreported (IUU) fishing of the International Tribunal for the Law of the Sea (ITLOS) and its contribution to the implementation of a renewed, ecosystem-oriented approach. Indeed, with that opinion the Tribunal reaffirmed its relevant role as a judicial body that fosters progressive interpretations on legal marine

brasileira de gestão dos recursos marinhos. In: Varella, Marcelo D. Revista de Direito Internacional, vol.12, no.1 (current edition).

10 FOOD AND AGRICULTURE ORGANIZATION OF THE UNITED NATIONS. The state of the world fisheries and aquaculture. Rome: FAO, 2012. issues. To the purpose of this paper, a special emphasis will be given on the Tribunal's understanding of the "due diligence" principle and the consequent consolidation of that originally environmental principle as one pillar of the LOS regime.

In the century when high-tech oceanic development takes off, some questions remains unanswered: what future is reserved to fisheries? Are there remedies to prevent the absolute depletion of fish stocks worldwide? Those are most serious enquiries that need be answered, and this paper is a drop in the ocean of contributions to analyze and offer possible solutions to the issue of IUU fishing.

\section{FisheRIES IN THE LOS AND THE CONFLICT BETWEEN PRINCIPLES: FREEDOM OF THE SEAS V. SOVEREIGNTY RIGHTS OVER NATURAL RESOURCES}

The Law of the Sea emerges in the context of growing "functional differentiation" within International Law. According to this phenomenon, the emergence of new subsystems is imposed by the growing complexity of contemporary problems, which, on its turn, demands global and sophisticated answers, of highly scientific and technical standards. ${ }^{11}$ For this reason, the LOS can be considered an international special regime of international law. Historically, it has been the narrative of a struggle between conflicting interests: those of maritime powers, nations with primordial interest in shipping and sailing the world's oceans, and those of coastal states interested essentially in the security of resources within their adjacent waters. ${ }^{12}$ According to that historical account, it is possible to understand the difference between "maritime" and merely "coastal" states, a distinction based on the state's ability and conditions to sail the seas.

The history of this specific realm of International Law is that of the division of the ocean between states, division into multiple jurisdictional spaces (amongst which the Exclusive Economic Zones, Continental

11 TEUBNER, Gunther; FISCHER-LESCANO, Andreas. Regime Collisions: the vain search for legal unity in the fragmentation of global law. Michigan Journal of International Law, v. 25, n. 4, 2004. 12 MCDORMAN, Ted L. The marine environment and the Caracas Convention on the Law of the Sea: a study of the third United Nations Conference on the Law of the Sea and other related marine environmental activities. Halifax: Dalhouise University Press, 1981. 
Shelves, and the high seas). Yoshifumi Tanaka names this division approach "zonal management approach", one deeply rooted in the history of LOS and resulting from the two antagonistic principles above mentioned: the principle of sovereignty and the principle of freedom (of navigation)..$^{13}$ Whilst one embodies the concept of territorial seas, the other gives place to the high seas and the freedom to navigate.

In other words, the conflicting nature of the LOS could be summed up to the ancient and opposing doctrines of "open seas" (mare liberum) and "closed seas" (mare clausum). Based on such fundamental opposition, the LOS has always been "made, changed, challenged and remade." 14 Each doctrine gives birth to different principles of the law of the sea. On the one hand, the mare liberum thesis in supported by the principle of the freedom of the seas, which had in Hugo Grotius its main defender. ${ }^{15}$ On the other, the mare clausum, defended by authors such as William Welwod.

Two of the founding fathers of International Law of the Sea, Hugo Grotius and Emmerich de Vattel, have pioneered in dedicating reflections to oceanic matters. Grotius laid the basis of the freedom of the seas principle, whereas de Vattel presented the modern concept of territorial seas, defined as jurisdictional waters, which form the territory of a state. ${ }^{16}$ Given it is not the purpose of this article to scrutinize the entire history of the LOS, a few words on the Grotian legal reasoning shall suffice to comprehend the ongoing dispute involving living resources in the seas.

In the $17^{\text {th }}$ century, following the Iberian restriction on shipping through the world's oceans, Grotius published his main thesis of the "community of the sea" and the freedom of fishing. Resorting repeatedly to analogies as well as to natural law, Grotius affirmed the basic customary rule of the Law of Nations, according

13 TANAKA, Yoshifumi. A Dual Approach to Ocean Governance: the cases of zonal and integrated management in International Law of the Sea. Paris: the Ashgate International Law Series, 2008. p. 2.

14 PIRTLE, Charles E. Military uses of ocean space and the law of the sea in the new millennium. Ocean Development and International Law, v. 31, n. 7, p. 11-32, 2000.

15 GROTIUS, Hugo. The Free Sea, trans. Richard Hakluyt, with William Welwod's Critique and Grotius's Reply, ed. David Armitage. Indianapolis: Liberty Fund, 2004. p. 95. Available at: <http:// oll.libertyfund.org/titles/859\#Grotius_0450_251>. Access on: 24 Mar. 2015.

16 VATTEL, Emmerich de. The Law of Nations: or Principles of the Law of Nature Applied to the Conduct and Affairs of Nations and Sovereigns. Philadelphia: Law Book Sellers, 1863. to which "it is lawful for any nation to go to any other and to trade with it". ${ }^{17}$ Neither the Portuguese, the Spaniards, nor the Dutch owned the oceans, and to defend this postulate, Grotius dives into the depths of Roman legal literature.

In acclaimed works of Ulpian, the Dutch author builds his central argument that the seas are by nature "open to all", and not just to citizens of a single state. For there is an abyssal distinction between conceptions of the sea as a "common good", as opposed to the seas as "public good". Given that the seas was common from its first origin, it is obvious that it cannot become entirely the property of anyone by nature. Therefore, says Grotius, "he who prohibits anyone else from fishing on the sea, whoever he is, commits a wrong." 18

Grotius examines the nature of the ocean and reaches the conclusion that the oceans, as something that cannot be limited physically, cannot be the property of one person, or people. ${ }^{19}$ Besides, provided the oceans need no cultivation to bear fruit (fish), than whatever exists inside of it is to be considered common, and any restrictions to sailing the seas or fishing should entail a legal damages action. ${ }^{20}$ De Vattel represented likewise a powerful voice against the ownership of the "open seas". In his words, "no nation has a right to take possession of the open seas or claim the sole use of it, to the exclusion of the others". This distinction between free, open seas and territorial waters marked the legal beginning of dualism between two distinct zones of the ocean.

Centuries onwards, maritime powers such as Portugal, Spain, The Netherlands, France, England, Canada, Russia, the United States, among others, sailed the seas with absolute freedom, trading with peoples from all parts of the world. Davor Vidas even relates the ideological foundation of the LOS to the mare liberum theory, and postulates that the freedom of the seas "facilitated the emergence of the forces that led to the Industrial

17 GROTIUS, Hugo. The Free Sea, trans. Indianapolis: Liberty Fund, 2004. p. 95.

18 GROTIUS, Hugo. The Free Sea, trans. Indianapolis: Liberty Fund, 2004. p. 95.

19 GROTIUS, Hugo. The Free Sea, trans. Indianapolis: Liberty Fund, 2004. p. 110.

20 After the publication of his main theses, and the reply to Welwod, it could be said that Grotius "won" the debate, because in 1609 King Phillip III of Spain and Portugal came to a temporary peace with the Dutch. The freedom of the seas was formally obtained. 
Revolution". ${ }^{21}$ Indeed, the freedom of the seas is a concept with a fascinating evolution, outcome of customary law and milestone for the free flow of commerce and communication between nations.

On the other side of the equation, coastal states that for centuries have watched the harvest of their natural resources by merchant fleets of developed countries were gradually claiming exclusivity to marine resources offshore. Consequently, after World War I traditional maritime states witnessed a stark decline in their powers within the international arena. Equally noteworthy was the increasing jurisdictional claims of developing states to secure ocean resources, mainly fisheries, which responded for a burgeoning part of their economic activity. In this juncture, the imminence of conflicts led coastal and maritime states to meet in The Hague in 1930 with the arduous task to codify the existing customary LOS. The Conference was organized by the League of Nations, but failed to produce a final document, given the already visible divergences between states.

A few years later, the continued failure to delimit the extent of territorial waters and fisheries jurisdiction stirred a move by the President of the US, which further promoted the division of the oceans. The Truman Proclamations of 1945, one on fisheries and another on the continental shelf, secured "property rights" over resources on the seabed and water column of the United States' continental shelf, and came as a model to be followed. Back then, several Latin American states took the same course of action and declared jurisdiction over their contiguous seas, triggering what McDorman names "the great expansion of coastal state jurisdiction." 22

Coastal states then advanced the national interest by controlling ocean resources, mainly fisheries, and prompted a series of "enclosures" of the adjacent waters to their coasts. This new phenomenon produced the unexpected problem of excessive claims by Latin American states due to the lack of harmonious international practice on this matter. Countries such as Brazil,

21 VIDAS, Davor; SCHEI, Peter Johan (Ed.). The world ocean in globalization: climate change, sustainable fisheries, biodiversity, shipping regional issues. Leiden: Nijhoff, 2011. p. 6.

22 See MCDORMAN, Ted. L. The marine environment [...], 1981, p. 2. Não tem na lista de referências. known for its "territorial ambitions" 23 , Argentina ${ }^{24}$ and Chile ${ }^{25}$ announced far-reaching declarations and proclaimed sovereignty over the continental shelf of whatever depth and additionally of a maritime areas extending 200 nautical miles from the shore. ${ }^{26}$ The unilateral delimitation of continental shelves by Latin American states became the rule, as Mexico, Nicaragua, Guatemala, Honduras, El Salvador and Ecuador imitated the action. $^{27}$

The rapid and unsystematic expansion of jurisdictional waters threatened the principle of the freedom of the seas and was, therefore, the raison d'etre of the 1958 Geneva Conference on the Continental Shelf. The UN-hosted Conference adopted four conventions, ${ }^{28}$ including the Convention on the Continental Shelf, and was responsible for bringing about new contributions to the LOS regime, as it fostered a "progressive development" of international law. For the first time, the basic features of the freedom of the seas principle was conversed into a treaty, and the so-called "zonal management approach" was finally codified. ${ }^{29}$ However, there was still work to be done, given that the specific

23 See VARGAS, Jorge A. Latin America and its contributions to the Law of the Sea. In: LAURSEN, Finn (Ed.). Towards a New International Marine Order. Leiden: Nijhoff, 1982. p. 58.

24 See Argentinian Declaration of 1946. Available at: <http:// legal.un.org/ilc/documentation/english/ a_cn4_30.pdf>. Visited on: 26 Apr. 2015.

25 See Chilean Declaration of 1947. Available at: <http://legal. un.org/ilc/documentation/english/ a_cn4_30.pdf>. Visited on: 26 Apr. 2015.

26 KIRCHNER, Andree. The Outer Continental Shelf: background and current developments. In: NDIAYE, Tafsir and WOLFRUM, Rüdiger. Law of the Sea, Environmental Law and Settlement of Disputes: Liber Amicorum Judge Thomas A. Mensah. Leiden: Nijhoff, 2007. p. 594.

27 Detailed information on the content of those unilateral declarations is available at ODA, Shigeru. Fifty years of the Law of the Sea: with a special section on the International Court of Justice. The Hague: Kluwer Law International, 2003. p. 19.

28 The four Conventions adopted were: the Convention on the Territorial Sea and the Contiguous Zone; the Convention on the High Seas; the Convention on Fishing and Conservation of the Living Resources of the High Seas, and the Convention on the Continental Shelf, all of them having entered into forced between 1962 and 1966. In addition, an Optional Protocol of Signature Concerning the Compulsory Settlement of Disputes was adopted, which entered into force on 30 September 1962. Available at: <http:// legal.un.org/diplomaticconferences/lawofthesea-1958/lawofthesea-1958.html>. Visited on: 27 Apr. 2015.

29 See TANAKA, Yoshifumi. A Dual Approach to Ocean Governance: the cases of zonal and integrated management in International Law of the Sea. Paris: The Ashgate International Law Series, 2008. p. 3. 
Convention on the Continental Shelf failed to specify the width of that zone, ${ }^{30}$ as well as the extent of state control over fisheries.

Less than a decade after the diplomatic Conference of 1958, disputes regarding sovereignty over natural resources on the offshore of coastal states, as well as on the high seas were still common. At that moment, the US had "landed" on the deepest underwater hole in the world, the Challengers Deep, in the Mariana Trench, ${ }^{31}$ located on the Pacific Ocean, and started worries about the possible exploitation of the seabed in ultra deep waters. As McDorman rightly points out, "the development of international ocean law owes as much to technological advancement as to scientific discovery," 32 and as such, the continental shelf regime itself, for instance, would not exist but for the introduction of ocean drilling and deep-water technologies. Such rapid technological developments inspired the idea of a fresh and more ambitious Convention on the Law of the Sea, capable of holistically addressing up-to-date issues of ocean governance worldwide.

At this moment, a new political phenomenon produced further legal consequences on the balancing between the principle of the freedom of the seas and the principle of sovereignty over natural marine resources. Indeed, as the decolonization wave shook the world, developing coastal states expanded their territorial seas and fisheries zones, therefore tightening legislative controls over their continental shelves, and consolidating a trend of jurisdictionalism over the oceans. ${ }^{33}$ Based on geographical arguments, Douglas Johnston provides a reasonable resume of the conflicting interests in the international arena. According to the author, "the naturally favored minority of states has had the strongest

30 In the words of McDorman, "the 1958 Conference did agree on a definition of the continental shelf, but that definition was formulated in such an elastic manner that it provided no useful way to determine the outer limit of the shelf". See MCDORMAN, Ted L. The marine environment [...], 1981, p. 3.

31 In 1960, the Swiss scientist Jacques Piccard designed a submersible vehicle with financial support of the U.S. Navy, and dove into the depths of the Challenger Deep, the deepest hole known in the world's oceans, in 1960

. In that occasion, the submersible Trieste descended 11.000 meters until the very bottom of the sea. The descent was expected to mark deep ocean explorations.

32 See MCDORMAN, Ted L. et al. International Ocean Law: materials and commentaries. Durham: Carolina Academic Press, 2005. p. 378.

33 See MCDORMAN, Ted L. The marine environment [...], 1981, p. 4. Não tem na lista de referências. interest in an extension of seaward limits of the continental shelf, whereas the majority of naturally unfavored states has had an interest in restricting encroachments on the international area of the deep ocean floor". ${ }^{34}$ In this juncture, opposition between principles was stronger than ever, and inspired the beginning of diplomatic conversations towards a new binding instrument.

The third United National Convention on the Law of the Sea was signed in 1982, in Montego Bay (Jamaica), and is the result of more than a decade of arduous negotiations, in one of the most impressive exercises of international negotiation in Public International Law. The cornerstone of UNCLOS III is believed to be Arvid Pardo's speech to the United Nations General Assembly in 1967, when Malta's ambassador to the UN presented a potent speech urging states to declare the seabed beyond national jurisdiction as common heritage of humankind $(\mathrm{CHH}) .{ }^{35}$ In the view of McDorman, "Arvid Pardo sought to halt this creeping jurisdictionalism by claiming that the seabed beyond national jurisdiction was the common heritage of mankind, to be managed for the benefit of all."36

As mentioned earlier, a greater change in the negotiations were the politically independent African and Asian states, which held a point of view differing significantly from those of their colonial predecessors. It was clear that the developing countries of the Third World, sympathetic to the political orientation of the so-called "Group of 77", ${ }^{37}$ played an important role in UNCLOS III negotiations. In this context, the UNCLOS III can

34 See JOHNSTON, Douglas M. The theory and history of ocean boundary making. Montreal: McGill-Queens University Press, 1988. p. 85.

35 Common space areas are regarded as regions owned by no one, though hypothetically managed by everyone. On the genderrelated issue, it should be noted that, although some reports prefer the gender-neutral equivalent "common heritage of humankind", the expression is widely quoted as "of mankind", and so will it be used on this dissertation.

36 One of the main purposes of the $\mathrm{CHH}$ principle is to protect areas beyond national jurisdiction or, when necessary, to allow exploitation in a way that enhanced the common benefit of humankind. For a detailed narrative on this principle, see GALINDO, George Rodrigo Bandeira. Quem diz bumanidade pretende enganar?: internacionalistas os usos da noção de patrimônio comum da humanidade aplicada aos fundos marinhos (1967-1994). 2006. PhD (Dissertation). Brasília: University of Brasília, 2006.

37 The political Group of 77 advocated a more radical form of $\mathrm{CHH}$ principle, based on the ideology underpinning the so-called "New International Economic Order", designed to rebalance economic relations between industrialized countries of the North and poorly developed states of the South. 
be associated to the intriguing phenomenon of the rise of coastal states, having simultaneously fulfilled old demands of sovereignty over marine resources, especially fisheries, and restricted disproportional territorial ambitions towards the seas. ${ }^{38}$

Despite challenging and long negotiations, ${ }^{39}$ the UNCLOS III has succeeded in designing a global architecture for ocean governance worldwide. It entered into force in 1994, after the sixtieth state had signed it, and has been ratified by 167 states, as to the first half of 2015. Even more importantly, "most of the significant concepts of the treaty have been absorbed by states into their national laws and practices over the last two decades." ${ }^{40}$ In fact, the Convention is often regarded as yielding quasi-universal principles, some of them grounded on customary international law of the sea, that is, in centuries of state practice..$^{41}$ In 320 articles, it managed to cover a broad range of oceanic issues, clarifying legal concepts (such as those of territorial sea, continental shelf, high seas, among others), determining seaward limits, ${ }^{42}$ and anticipating future challenges, especially the ever closer commercial exploitation of marine resources lying on the deep seabed.

The UNCLOS III, alongside other instruments, ad-

38 Regarding the tension between the freedom of the seas and sovereignty claims of Third World countries towards the ocean, it seem relevant to mention the Freedom of Navigation Program (FON) of the U.S. Navy. In force since 1979, a few years before the UNCLOS III was open to signatures, this program has the main goal of highlighting "navigation provisions of the LOS Convention to further the recognition of the vital national need to protect maritime rights throughout the world". Available at: <http://www.state. gov/e/oes/ocns/opa/maritimesecurity/>. Visited on: 28 Apr. 2015. 39 The UNCLOS III is the treaty with the longest negotiation record in the history of the United Nations. See FREESTONE, David. Problems of high seas governance. In: VIDAS, Davor; SCHEI, Peter Johan. The world ocean in globalization: climate change, sustainable fisheries, biodiversity, shipping, regional issues. Leiden: Nijhoff, 2011. p. 100. 40 See MCDORMAN, Ted L. et al. The entry into force of the Law of the Sea Convention and South-East Asia: an introductory comment. In: MATICS, K. I.; MCDORMAN, T. (Ed.). Selected papers in commemoration of the entry into force of the U.N. Convention on the Law of the Sea. Bangkok: SEAPOL, 1995. p. 5.

41 The absence of countries such the United States, Turkey, Venezuela, Israel, among others, poses a challenge to the international society, but does not impede the application of the LOS. Indeed, despite not signing the treaty, those countries are bound by customary ocean norms, mainly those concerning rights and duties of states in maritime zones such as the EEZ, CS and others. Those provisions are thus opposable even against non-states parties to the Convention.

42 On this topic, see JOHNSTON, Douglas M. The theory and history of ocean boundary making. Montreal: McGill-Queens University Press, 1988. vanced many topics that have helped consolidate the regime of the LOS. That notwithstanding, there is still much to be done on implementing these instruments. Challenges ahead of the ocean governance amount to: marine (oil) pollution, invasive alien species, habitat destruction, and, for the purpose of this contribution, poorly managed fisheries. Indeed, more than 20 years after the entry into force of the Convention, coastal states call for new protocols and agreements to address unfinished agendas, such the legal framework applicable to the high seas. ${ }^{43}$ As Vladimir Golitsyn, judge at the ITLOS, would put it, the international society needs to promote a shift from an approach that emphasizes "entitlement to", to one that highlights "responsibility for" the oceans, so as to grant application both in areas within and outside national jurisdiction, without disregarding the jurisdictional dimension. ${ }^{44}$ In the light of this "exploitation-oriented" approach, which is still perceptible in UNCLOS III, a question that, therefore, remains is to whether and how international lawyers and institutions applying the UNCLOS III could tackle one of the main challenges of current state of affairs in ocean law: the practice of IUU fishing.

\section{IUU FISHING: DEFINITION AND GLOBAL EFFORTS TO FRAME THE PROBLEM}

As pointed out at the introductory part, IUU fishing consists of a global scale problem that affects not only the sustainability of fishing stocks, but also the lives of hundreds of millions in fishing communities throughout the world that have on fishing their main subsistence source. ${ }^{45}$ When fishing is conducted in violation of internationally agreed regulations and catch quotas, consequences also reach fishers that abide by the law, stimulating, therefore, non-compliance to international duties, in a destructive downward spiral.

43 See FREESTONE, David. Problems of high seas governance. In: VIDAS, Davor; SCHEI, Peter Johan. The world ocean in globalization: climate change, sustainable fisheries, biodiversity, shipping, regional issues. Leiden: Nijhoff, 2011. p. 100.

44 See GOLITSYN, Vladimir. Major challenges of globalization for seas and oceans: legal aspects. In: VIDAS, Davor; SCHEI, Peter Johan. The world ocean in globalization: climate change, sustainable fisheries, biodiversity, shipping, regional issues. Leide: Nijhoff, 2011. p. 61. 45 See CULLIS-SUZUKI, Sarika; DANIEL, Pauly. Failing the high seas: a global evaluation of regional fisheries management organizations. Marine Policy, 2010. p. 1. 
IUU fishing is not an exclusively legal problem, and although it is not the aim of this paper to address other roots of that illegal activity, it is relevant to briefly call attention to some of the factors that contribute to the steadiness of global landings of illegally caught stocks. Rachel Baird identifies the following reasons: "the impact of the industrialization of the fishing industry; increases in both human consumption and the size of the global fishing fleet; the introduction of government subsidies which have contributed to the creation of an artificial environment of profitability; increased competition amongst fishers and the entry of large scale commercial fishing entities into the marine fishing industry IUU fishing is also very common, and even more difficult to tackle, on the high seas." ${ }^{46}$ These aspects evidence the multifaceted nature of overfishing problems, which in their turn demand integrated and holistic responses.

This is not to mention the greater challenge of tackling IUU fishing on the high seas. ${ }^{47}$ Marine living resources beyond national jurisdiction received scant attention during the negotiation of the UNCLOS III, for it focused upon the authority of coastal states respecting marine living resources within national zones. ${ }^{48}$ On the high seas, states are free to harvest (art. 116 of the Convention), although there are uncertain duties respecting cooperation and marine conservation. A normative attempt to limit flag states arbitrariness is enshrined in art. 117 on UNCLOS III, within section 2 , devoted to the conservation and management of the living resources on the high seas. According to article 117 , states must cooperate with each other in order to adopt measures (with respect to their nationals) for the conservation of living resources of the high seas. What specific measures shall be adopted is, nevertheless, va-

46 See BAIRD, Rachel J. Aspects of illegal, unreported and unregulated fishing in the Southern Ocean. Dordrecht: Springer, 2006. p. 8.

47 On the topic of the effectiveness of ocean governance in areas beyond national jurisdiction, David Freestone sees very slow progress. For that reason, the author is of the opinion that a new instrument based on agreed modern principles of LOS could be a way to tackle current problems. Such new instrument would "pull together all the various themes and sectoral responsibilities discussed above and provide some overarching system of governance of the high seas". See FREESTONE, David. Problems of high seas governance. In: VIDAS, Davor; SCHEI, Peter Johan. The world ocean in globalization: climate change, sustainable fisheries, biodiversity, shipping, regional issues. Leiden: Nijhoff, 2011. p. 130.

48 See MCDORMAN, Ted L. et al. International Ocean Law: materials and commentaries. Durham: Carolina Academic Press, 2005. p. 264-5. gue. ${ }^{49} \mathrm{On}$ this quest, enforcement of international regulations is to be done exclusively by the flag state of the offending vessel. ${ }^{50}$

In order to match issue of IUU fishing, be it on national or international levels, international lawyers and decision-makers rely on the current legal framework that not only allows for, but also demands states to cooperate with each other in facing IUU threat. Besides the UNCLOS III, as a framework convention, states have signed the Straddling Fish Stocks Agreement in New York, 1995, with the main goal of enhancing the cooperative management of fisheries resources that occur in wide areas. It provides states with solid ground for the creation of Regional Fisheries Management Organizations (RFMO), which are "the only legally mandated fisheries management bodies on the high seas". ${ }^{51}$ This means that domestic commercial fishing fleets are obliged to abide those organizations' rules in order to fish in those areas. On this particular, it should be added that observers are skeptical as to the success of those organizations in fulfilling announced goals. ${ }^{52}$

49 Interesting enough is to note that maritime states with wellequipped coastal guards have attempted in the past to act unilaterally in combating IUU fishing on the high seas. It is the case of the unilateral action of the Canadian Coast Guard, who seized the Spanish fishing trawler Estai, caught fishing immediately off Canada's EEZ $200 \mathrm{~nm}$ limits. Despite good intentions and alleged ecological necessity, "neither customary nor conventional law of the sea permits one state to forcibly seize the fishing vessel of another state on the high seas for engaging in illicit fishing on the high seas, according to McDorman. The episode was known as the "Turbot war", and was pacifically solved when the European Union and Canada entered into an agreement in April 1995. See MCDORMAN, Ted L. et al. International Ocean Law: materials and commentaries. Durham: Carolina Academic Press, 2005. p. 265.

50 Despite the introduction of a global Unique Vessel Identifier (UVI) on fishing vessels, irrespective of the flag of the ship, the responsibility to enforce international obligations lies ultimately with the flag state. The UVI is a record given to ships that ensure reliable traceability and that marks the vessel for its entire life, regardless of changes in flag. It is part of a greater international effort to create a global record of fishing vessels, an important step in fighting illicit activities at the seas. For further information, see: UNITED NATIONS. Report of the Expert Consultation on the Development of a Comprehensive Global Record of Fishing Vessels. FAO, Rome, 2008.

51 FOOD AND AGRICULTURE ORGANIZATION OF THE UNITED NATIONS. Straddling Fish Stock Agreement. New York: FAO, 1995.

52 Cullis-Suzuki and Pauly draft harsh critiques on the inability of RFMOs to achieve their main conservation goals in the high seas, due to individual and organizational problems, to the continued articulation of the principle of freedom of fishing, as well as to lack of genuine commitment. See: CULLIS-SUZUKI, Sarika; DANIEL, Pauly. Failing the high seas: a global evaluation of regional fisheries management organizations. Marine Policy, 2010. p. 7. 
Following this borderless effort to combat illicit fishing, the Organization for Economic Co-operation and Development (OECD) equipped its own fisheries division, responsible for elaborating not only reports on the status of IUU fishing, but also possible courses of actions for all actors involved. According to the methodology adopted by the reports, each of the terms contained in IUU fishing

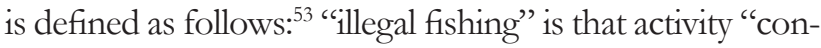
ducted by vessels of countries that are parties to a Regional Fisheries Management Organization (RFMO) but operate in violation of its rules, or operate in a country's waters without permission". "Unreported fishing" refers to that "catch not reported or misreported to national relevant authorities or RFMO". Finally, "unregulated fishing" is considered that "conducted by vessels without nationality or flying the flag of States not parties of relevant fisheries organizations and who therefore consider themselves not bound by their rules." ${ }^{54}$ Needless to highlight that these categories might cumulate in specific cases.

Another important actor in the struggle against IUU fishing is the FAO, as already pointed out in the introductory remarks. The Organization counts on a specific department and a Committee on Fisheries (COFI), based on the premise that a shortage of fishes would negatively affect food security in the planet. For that reason, the Committee has adopted in 2014 the Voluntary Guidelines for Flag State Performance, ${ }^{55}$ which establishes criteria to clarify the obligations assumed by states. Noteworthy enough, those obligations could be regarded as of "due diligence" towards port-state duties and the registration of vessels. In fact, paragraph 2 of the Guidelines establish that flag states should:

(c) prevent, deter and eliminate IUU fishing or fishing related activities in support of such fishing; (d) effectively exercise its jurisdiction and control over vessels flying its flag; (e) take measures to ensure that persons subject to its jurisdiction, including owners and operators of vessels flying its flag, do not support or engage in IUU fishing or fishing related activities in support of such fishing..$^{56}$

53 The definition of IUU fishing adopted by the OECD resembles the one put forward by the IPOA-IUU adopted by the FAO and analyzed at the introductory chapter of this paper.

54 See SCHIMDT, Carl-Christian. Addressing Illegal, Unreported and Unregulated (IUU) Fishing. International Fisheries Compliance Conference, Brussels, 2004. Available at: <http://www.oecd.org/greengrowth/fisheries/34029751.pdf>. Access on: 29 Apr. 2015.

55 FOOD AND AGRICULTURE ORGANIZATION OF THE UNITED NATION. Voluntary Guidelines for Flag State Performance, Rome: FAO, 2014. Available at: <http://www.fao.org/fishery/topic/16159/en>. Visited on: 29 Apr. 2015.

56 FOOD AND AGRICULTURE ORGANIZATION OF THE UNITED NATION. Voluntary Guidelines for Flag State Perfor-
Moreover, other key soft law instruments are the Code of Conduct for Responsible Fisheries (1995) and the Rome Declaration on Illegal, Unreported and Unregulated Fishing (2005), the latter adopted by the FAO Ministerial Meeting on Fisheries. In short, the Code of Conduct has the main goal to provide "principles and standards applicable to the conservation, management and development of fisheries", covering the capture, processing and trade of fish and fishery products, and the integration of fisheries into coastal area management, according to article $1 .{ }^{57}$ The 2005 Rome Declaration calls for effective implementation efforts of already existing rules. Both the Code of Conduct and the Voluntary Guidelines confirm the leading role of FAO's action plans in tackling IUU fishing. Nonetheless, stronger coordination between international organizations (including the International Maritime Organization - IMO) and states, especially focused on increasing the accuracy of marine scientific data on fisheries, could represent a major step in fighting illegal fishing.

Finally, the UNGA Resolution 61/105, approved in 2006, calls upon states to take action immediately, individually and through regional fisheries organizations and arrangements to manage fish stocks sustainably and protect vulnerable marine ecosystems from destructive fishing practices. Indeed, according to paragraph 5, states ought to apply widely "the precautionary approach and an ecosystem approach to the conservation, management and exploitation of fish stocks." This resolution incorporates the need for a closer interplay between LOS and environmental considerations, especially the integrated approach, if the sustainable exploitation of fisheries is to succeed. Such interaction is ongoing, especially regarding the high seas framework, which according to Freestone, "was transformed by the new concerns for ecosystem maintenance and conservation of biological diversity." 58

mance. FAO, Rome: FAO, 2014. p. 6.

57 FOOD AND AGRICULTURE ORGANIZATION OF THE UNITED NATION. Code of Conduct for Responsible Fisheries. Rome, 1995. Available at: <http://www.fao.org/docrep/005/ v9878e/v9878e00.htm>. Visited on: 29 Apr. 2015.

58 See FREESTONE, David. Problems of high seas governance. In: VIDAS, Davor; SCHEI, Peter Johan. The world ocean in globalization: climate change, sustainable fisheries, biodiversity, shipping, regional issues. Leiden: Nijhoff, 2011. p. 118. 


\section{From the zonal to a more integrated APPROACH TO THE MANAGEMENT OF FISHERIES}

Grotius' assumptions underpinning the mare liberum theory are now fundamentally outdated. Unlike the panorama that the Dutch author had at hand, ocean resources are currently known to be finite, with overfishing already threatening entire species; states nowadays have all technological means to establish maritime boundaries with amazing precision; and regardless of how immense oceans are, maritime conflicts are most likely to arise, due also to an international security agenda set forward after 9/11 and the "war on terror". Confirming this rationale, Shaw considers that "the predominance of the concept of the freedom of the high seas has been modified by the realization of resources present in the sea and the seabed beyond the territorial sea." 59

The traditional approach, based on the opposition between sovereignty rights and the freedom of the seas, has proven insufficient to tackle current challenges, mainly those related to the sustainable exploitation of the world's fisheries. In line with Yoshifumi Tanaka, three main problems undermine effectiveness in fighting issues such as IUU fishing. Firstly, the separation between law and nature, when marine spaces are divided spatially. If one considers that the distance criterion ignores ecological interactions between marine species and ecological conditions, it becomes clear the need to develop a broader approach to the governance of large marine ecosystems. In the words of Tanaka, "as the ocean is a dynamic natural system, it is logical that international law of the sea must take the dynamics of nature into account", what has not been optimally happening in the past decades, as will be explained later on. ${ }^{60}$

The second main difficulty refers to the ongoing sectorial approach to different fields of LOS, such as shipping, fishing and environmental protection, thus ignoring interrelationships between marine issues. In legal literature, the need to "focus on the interplay between marine issues from holistic viewpoints" is of-

59 See SHAW, Malcolm. International Law. 6. ed. Cambridge: CUP, 2008. p. 554

60 See TANAKA, Yoshifumi. A Dual Approach to Ocean Governance: the cases of zonal and integrated management in International Law of the Sea. Paris: The Ashgate International Law Series, 2008. p. 6. ten emphasized, ${ }^{61}$ regardless of how demanding such a shift might be. Thirdly, the two traditional principles of sovereignty over marine resources and freedom to roam the seas pose challenges to the implementation of sound sustainable practices in managing fisheries and, consequently, need a revision. When it comes to the protection of marine living resources, the "freedom of the seas" loses its validity. Instead of the laissez-faire freedom system, states ought to focus on the "duty to have due regard to the rights of other States and the need of conservation for the benefit of all." ${ }^{62}$ Similarly, instead of the absolute principle of sovereignty, a legal framework capable of resolving problems of marine pollution and conservation of living resources within maritime zones of states should be stimulated.

For those reasons, the quest for a more "integrated management approach" would not only add coherence and completeness to the LOS, but also contribute to tackling IUU fishing. Such an approach is already present in international instruments, for instance, the Agenda 21, adopted after the Rio Conference of 1992, and the UN General Assembly Resolution 60/30, agreed in 2009. While the former advanced the integrated approach to the planning and management of land resources (principle 10.1), ${ }^{63}$ the latter included socio-economic aspects to the reporting and assessment of the status of marine environments (par. 89), in an attempt to grasp a broader picture of the ongoing marine conservation efforts. ${ }^{64}$ The problem lies on the fact that those international instruments use this approach in a rather loose manner, given the conceptual blurriness of "integrated". There is not a definition, but a purpose, which is to outreach the traditional approach, and face challenges more effectively, amongst which IUU fishing. ${ }^{65}$

61 Se TANAKA, Yoshifumi. A Dual Approach to Ocean Governance: the cases of zonal and integrated management in International Law of the Sea. Paris: The Ashgate International Law Series, 2008. p. 7. 62 ICJ, Fisheries Jurisdiction Case, United Kingdom v. Ireland, 1974.

63 FOOD AND AGRICULTURE ORGANIZATION OF THE UNITED NATIONS. Agenda 21, World Conference on Environment and Development. Rio de Janeiro, 1992.

64 The UN Resolution 60/30 was suggested by the Intergovernmental Oceanographic Commission of the UNESCO. Available at: <http://ioc-unesco.org/index.php?option $=\mathrm{com}_{-}$ oe\&task=viewDocumentRecord\&doc ID $=4289>$. Visited on: 29 Apr. 2015.

65 As for the concept of "international community" and its multifaceted nature, see SIMMA, Bruno; PAULUS, Andreas. The international community: facing the challenges of globalization. EJIL, v. 9, n. 2,1998 
It is now clear that the challenges to a sustainable marine governance are manifold and call for an urgent migration from sectorial responses to integrated policies, ${ }^{66}$ which would imply some steps to achieve a sound marine environmental status. Policies that take into account the multidimensional status of environmental protection and, accordingly, consider economic, technological and political factors. As Tanaka rightly puts it, "since conservation measures inevitably affect national development, there is a need to reconcile these measures with the economic, technological and political circumstances of every state." ${ }^{97}$ On an international judicial level, the advisory opinion on flag state responsibility for IUU fishing recently rendered by the ITLOS might represent a step towards a renewed, ecosystem-oriented approach to oceanic problems.

\section{The Advisory Opinion of the ITLOS: aVant guardisme In the LaW of the Sea}

The UNCLOS III is based, regarding fisheries' issues, on the principle of exclusive jurisdiction of the flag state, although the current panorama shows that the principle alone is inadequate for ensuring compliance with and enforcement of rules. Bearing these considerations in mind, and looking forward to improved manners to hold flag states responsible, the Sub-Regional Fisheries Commission (SRFC) submitted a request for advisory opinion to the International Tribunal for the Law of the Sea (ITLOS) in March 2013. ${ }^{68}$ Interesting enough, it was the first time that the full Tribunal

66 In the case of the European Union, a major step was taken with the adoption of the European Directive on Marine Strategy Framework (2008), according to which 11 qualitative descriptors outline what the document defines as "good environmental status". The main and ambitious goal of the Directive is to provide diverse and dynamic oceans and seas, which are clean, healthy and productive (overall aim of promoting sustainable use of the seas and conserving marine ecosystems). See CHURCHILL, Robin. The European Union and the challenges of marine governance: from sectoral response to integrated policy? In: VIDAS, Davor; SCHEI, Peter Johan. The world ocean in globalization: climate change, sustainable fisheries, biodiversity, shipping, regional issues. Leide: Nijhoff, 2011.

67 See TANAKA, Yoshifumi. A Dual Approach to Ocean Governance: the cases of zonal and integrated management in International Law of the Sea. Paris: the Ashgate International Law Series, 2008. p. 241.

68 Such a procedure is established in article 138 of the Rules of the Tribunal, which grants ITLOS jurisdiction over contentious and advisory cases. rendered an advisory opinion, instead of just a special chamber, and in April 2015, the ITLOS published the definitive Advisory Opinion. ${ }^{69}$

The SRFC focused, in four questions, on assessing both the responsibility and liability of flag states upon IUU fishing activities conducted within the EEZ of third party states. ${ }^{70}$ The original questions were:

1. What are the obligations of the flag State in cases where illegal, unreported and unregulated (IUU) fishing activities are conducted within the Exclusive Economic Zone of third party States?

2. To what extent shall the flag State be held liable for IUU fishing activities conducted by vessels sailing under its flag?

3. Where a fishing license is issued to a vessel within the framework of an international agreement with the flag State or with an international agency, shall the State or international agency be held liable for the violation of the fisheries legislation of the coastal State by the vessel in question?

4. What are the rights and obligations of the coastal State in ensuring the sustainable management of shared stocks and stocks of common interest, especially the small pelagic species and tuna?

The organization responsible for the request to the ITLOS is an intergovernmental organization created in 1985 by a Convention that united Cabo Verde, Gambia, Guinea, Guinea-Bissau, Mauritania, Senegal, and Sierra Leone in the struggle against the depletion of living resources off their coasts. Already on the preamble, the Sub-Regional Commission stresses the relevance of coastal states to cooperate among each other and harmonize domestic policies on fisheries, so as to rea-

69 See ITLOS. Advisory Opinion on the Request submitted to the Tribunal by the Sub-Regional Fisheries Commission. Case 21, Hamburg, 2015. For complementary views on the advisory opinion, see: OLIVEIRA, Carina Costa de, and MALJEAN-DUBOIS, Sandrine. Os limites dos termos bem público mundial, patrimônio comum da humanidade e bens comuns para delimitar as obrigações de preservação de recursos marinhos. In: Varella, Marcelo D. Revista de Direito Internacional, vol.12, no.1 (current edition). See also: OLIVEIRA, Carina Costa de. Comentário à Opinião Consultiva 21 do Tribunal Internacional para o Direito do Mar [02/04/2015] In: Varella, Marcelo D. Revista de Direito Internacional, vol.12, no.1 (current edition).

70 Flag States such as Panama and Togo are often cited as "safe havens" for irregular vessels that engage in IUU fishing activities. The practice of granting "flags of convenience" to troubled ships is also widespread, despite the detrimental effects they bear to the management of fisheries worldwide. The Environmental Justice Foundation provides detailed information on "flags of convenience" and states engaged in this practice. See ENVIRONMENTAL JUSTICE FOUNDATION. Pirates and profiteers: how pirate fishing fleets are robbing people and oceans. London, 2005. 
ch a balance between conservation and exploitation of those resources. As it could not have been different, the economic and political element of national development was present, as well as the care for the nutritional needs of local populations. ${ }^{71}$

The Sub-Regional Commission illustrates long-ranged sight and good intentions in the struggle against IUU fishing within maritime zones of its member states. Amongst the objectives of the SRFC, emphasis is added to the coordination of policies in terms of the adoption of international best practices, the development of sub-regional cooperation with regard to tracing, controls and surveillance, and the improvement of members' research capacities in fisheries sciences on the sub-regional level. Besides local efforts to repress illegal fishing, it should be praised that the Commission, which is legally entitled to stand before courtrooms, has also engaged in juridical battles in order to achieve the main goal of sustainable fishing activities.

Following the request for the advisory opinion, the Tribunal received two rounds of written statements by a plethora of international actors, including Member States to the UNCLOS III, States Parties to the 1995 Straddling Fish Stocks Agreement, ${ }^{72}$ Intergovernmental Organizations, ${ }^{73}$ as well as Non-Governmental Organizations. ${ }^{74}$ At this moment, several states raised preliminary questions alleging the lack of jurisdiction of the Tribunal to render advisory opinions. Countries such as the United States, China, Australia, Spain, the United Kingdom, Ireland, among others, have supported this claim. $^{75}$

71 In the original document, written in French, contracting states highlight "la nécessité, pour les pays riverains, de coopérer et d'oeuvrer en vue de l'harmonisation de leurs politiques en matière de préservation, de conservation et d'exploitation des ressources halieutiques de la sous-région, ainsi que le besoin de coopérer au développement de leurs industries nationales de pêche." See Convention of Sub Regional Fisheries Commission, Praia, Cabo Verde, 1985. Available at: <http://www.spcsrp.org/medias/csrp/documents/ CSRP-1993-ConvPraya.PDF>. Visited on: 25 Apr. 2015.

72 The United States presented a statement as member of this treaty, given that they have not ratified the UNCLOS III so far.

73 Important intergovernmental organizations to pronounce on this case were: the Forum Fisheries Agency, the International Union for Conservation of Nature and Natural Resources, the Caribbean Regional Fisheries Mechanism, the United Nations, the Food and Agriculture Organization of the United Nations, and the Central American Fisheries and Aquaculture Organization.

74 The World Wildlife Fund (WWF) acted as amicus curiae by submitting a brief.

75 Noteworthy is the fact that the Republic of China is known for massively engaging in IUU fishing in several regions of the
On the preliminary questions, the judges decided unanimously that the Tribunal has conventional jurisdiction to entertain requests for advisory opinions. According to the decision, the UNCLOS III does not encapsulate the contentious function of the Tribunal, whose Statute (Annex VI) allows for it. The ITLOS has jurisdiction to decide on "all matters", which encompasses more than just disputes. If it were not so, the legal wording should expressly display "disputes". That is the result of a combined interpretation of articles 21 and 138 of the Statute of the ITLOS. ${ }^{76}$ Besides, the Tribunal considered that the questions asked were legal in nature, for they were made in terms of law and demanded complex juridical interpretation in order to render an opinion. Moreover, consistent with paragraph 77 of the opinion, "the Tribunal is mindful of the fact that by answering the questions it will assist the SRFC in the performance of its activities and contribute to the implementation of the Convention." For this reason, amongst others, the ITLOS deemed it appropriate to render the advisory opinion.

As for the material content of the opinion, in general lines, the Tribunal considered that the flag state has a duty "to ensure" that vessels flying its flag abide by the law of coastal states where fishing activities are taking place. The "responsibility to ensure" is enshrined in the provisions of article 58 (3) (rights and duties of other states in the EEZ), article 62 (4) (utilization of the living resources), and article 192 (general obligation to protect and preserve the marine environment) of the UNCLOS III. The combined interpretation of those instruments leads to the conclusion that flag states have to take the necessary measures to ensure that vessels flying its flag are not engaged in IUU fishing activities.

The "responsibility to ensure" does not lead, however, to automatic liability of flag states for wrongdoing of ships flying their flags. When tackling this question, the Tribunal explicitly referred to the obligations of "due diligence" from article 125 to 140 , and made a

globe. See: LARSEN, Christina. China's illegal fishing expeditions threaten world's waters. Bloomberg Business. November 19, 2013. Available at: <http://www.bloomberg.com/bw/articles/2013-11-19/chinas-illegal-fishing-expeditions-threaten-world-waters $>$. Access on: 26 Apr. 2015.

76 Article 21 of the Statute reads, "The jurisdiction of the Tribunal comprises all disputes and all applications submitted to it in accordance with this Convention and all matters specifically provided for in any other agreement, which confers jurisdiction on the Tribunal." 
clear distinction between obligations of "due diligence" and obligations of result. ${ }^{77} \mathrm{~A}$ remarkable development is, however, the reinforcement of the principle of due diligence and of "obligations of conduct" in the LOS. According to the reasoning of the ITLOS, the obligation of due diligence

\begin{abstract}
$[\ldots]$ is not an obligation of the flag State to achieve compliance by fishing vessels flying its flag in each case with the requirement not to engage in IUU fishing in the exclusive economic zones of the SRFC Member States. The flag State is under the "due diligence obligation" to take all necessary measures to ensure compliance and to prevent IUU fishing by fishing vessels flying its flag. ${ }^{78}$
\end{abstract}

The opinion based on the obligations of "due diligence" reinforces previous international case law. The Pulp Mills on the River Uruguay case, before the International Court of Justice (ICJ), is a case in point. Comprising a dispute between Argentina and Uruguay, the contention related to the construction and operation of pollutant pulp mills on the banks of the River Uruguay, i.e. on the borders of both countries. In the best interest of this paper, it is notable that the Court outlined, although superficially, the content of due diligence obligations. The final ruling considers that such obligations "entail not only the adoption of appropriate rules and measures, but also a certain level of vigilance in their enforcement and the exercise of administrative control applicable to public and private operators, such as the monitoring of activities undertaken by such operators, to safeguard the rights of the other party." 79

Within the jurisprudence of the ITLOS, efforts to consolidate the "due diligence" principle began in 2011, when the Seabed Disputes Chamber addressed a Request of the International Seabed Authority regarding "responsibilities and obligations of states sponsoring persons and entities with respect to activities in the Area". ${ }^{80}$ The content of the "due diligence" obligation,

77 Among the obligations of due diligence established by the UNCLOS III and relating to the fighting of IUU fishing, the following deserve special attention: the obligation to inform, to cooperate (art. 64 (1) UNCLOS III), to ensure the adoption of conservation and management measures (article 61, UNCLOS III), and to undertake mutual consultations (article 300, UNCLOS III) with third states on whose coast IUU fishing activities are being conducted.

78 ITLOS, Advisory Opinion on the Request submitted to the Tribunal by the Sub-Regional Fisheries Commission. Case 21, 2015, para. 129.

79 See Pulp Mills on the River Uruguay case, (Argentina v. Uruguay), Judgment, ICJ, para. 197.

80 The ISBA is an organization created by the UNCLOS III although still vague, was scrutinized between paragraphs 110 and 120 of that opinion.

In paragraph 110, ITLOS considered that the obligation of due diligence is not an obligation of result, but an obligation of means. In fact, "[t]he sponsoring State's obligation "to ensure" is not an obligation to achieve, in each and every case, the result that the sponsored contractor complies with the aforementioned obligations. Rather, it is an obligation to deploy adequate means, to exercise best possible efforts, to do the utmost, to obtain this result. To employ terminology dear to international law, this obligation may be characterized as an obligation "of conduct" and not "of result", as well as an obligation of "due diligence". The relevance of this previous case law should not be underestimated, given that in the Advisory Opinion on flag states responsibility for IUU fishing, the Tribunal refers several times to those two decisions in order to base its legal reasoning. ${ }^{81}$

It is likely that the opinion be welcomed with skepticism, especially by coastal states who awaited more precise considerations on flag state responsibilities. It might also not have been the dream opinion expected by the international legal scholarship, because the ITLOS essentially denied to stipulate any concrete "measure" that flag states are obliged to undertake in fulfilling the "due diligence" principle. ${ }^{82}$ In fact, if the flag state

alongside the International Tribunal for the Law of the Sea. For detailed information on this treaty body, see: CHIRCOP, A. E. Operationalizing Article 82 of the United Nations Convention on the Law of the Sea: A New Role for the International Seabed Authority? Ocean Yearbook, v. 18, 2004. Institutional information on the ISBA. Available at: <https://www.isa.org.jm/> Visited on: 28 Apr. 2015. 81 The resort to analogies and to jurisprudence of the ICJ is harshly criticized by Judge Cot, who considers that this strategy weakens the Court to the eyes of the international community. His separate opinion reads: "Ma réserve principale tient au refus, par le Tribunal, d'assumer l'exercice de son pouvoir discrétionnaire de répondre ou non aux questions qui lui sont posées dans une procédure contentieuse. Pour justifier ce refus, le Tribunal s'abrite derrière la jurisprudence de la Cour internationale de Justice et déclare qu'il est bien établi qu'une demande d'avis consultatif ne doit pas être rejetée, sauf pour des " raisons décisives ». (Declaration of Judge Cot, par. 5).

82 On their separate opinions, Judges Wolfrum and Lucky have highlighted some discontent themselves. On the one hand, Judge Wolfrum considers that the advisory opinion could and should have been more detailed on its considerations, besides addressing the issue of reparation of damages, as established by the Draft Articles of the ILC on State Responsibility for Wrongful Acts (Declaration of Judge Wolfrum, par. 1). On the other hand, Judge Lucky highlighted the creative role of international judges in welcoming new approaches and considering technological advancements (Declara- 
can prove that all necessary measures to prevent IUU fishing were duly taken, it shall not be held liable for damages produced. ${ }^{83}$ In this juncture, to prove that administrative measures preceded the registration of fishing vessel could theoretically shield flag states against compensation claims. Besides such an elusiveness, the advisory opinion was also explicit in confining its effects to the EEZ of the member States to the SRFC, leaving the responsibilities of flag states for IUU fishing on the high seas for a coming opinion. ${ }^{84}$

Dissatisfactions aside, the advisory opinion ought to be praised for the positive developments it entails. Firstly, it consists of an international decision situated in an important intersection between fields of international law, and the permeability between such fields deserves to be further stimulated. In the opinion, the Tribunal approached the LOS with lenses of two different regimes of international law: principles of state responsibility and of international environmental law. ${ }^{85}$ Despite the vagueness of considerations, to invoke the principle of "due diligence" in the law of the sea, a principle still in the making, with strong environmental foundations, is to foster the shift from a purely traditional approach towards an integrated approach to the solution of ocean issues.

Secondly, although the Tribunal avoided specifically addressing the environmental facet of "due diligence" obligations, it is likely that future proceedings will ground claims on the objective breach of "due diligence" obligations. Intergovernmental organizations dedicated to fisheries governance have from now on a concrete foundation to base future claims of compensation for IUU fishing. The opinion, therefore, fosters states to adopt binding requirements, for instance, for the registration of

tion of Judge Lucky, par. 12).

83 Paragraph 146 of the Advisory Opinion reads: "the liability of the flag State does not arise from a failure of vessels flying its flag to comply with the laws and regulations of the SRFC Member States concerning IUU fishing activities in their exclusive economic zones, as the violation of such laws and regulations by vessels is not per se attributable to the flag State." See: Advisory Opinion on the Request submitted to the Tribunal by the Sub-Regional Fisheries Commission. ITLOS, Case 21, 2015.

84 Paragraph 154 reads: "the Tribunal considers that, in light of its conclusion that its jurisdiction in this case is limited to the exclusive economic zones of the SRFC Member States [...]." See: Advisory Opinion on the Request submitted to the Tribunal by the Sub-Regional Fisheries Commission. ITLOS, Case 21, 2015.

85 On the interaction between special regimes of international law, see VENTURA, Victor Alencar Mayer Feitosa. Ecologização do direito internacional bumanitário: proteção ambiental em tempos de guerra. João Pessoa: UFPB, 2014. fishing vessels. This measure would enable authorities to fight illegal fishing in a more efficient manner. Besides, those binding standards would support claims of flag state responsibility for illegal fishing, what could de-stimulate the emission of those flags of convenience and consequently represent a blow to IUU activities.

Hence, the content and extension of the principle should be systematically outlined, in order to prospectively delimit the substance of those "obligations of means" that influence the effectiveness of the struggle against IUU fishing. It is also possible that the advisory opinion be interpreted in an extensive fashion, so as to comprise maritime zones other than just the EEZ of member states to the SRFC, therefore, including the much fragile high seas. Overall, the Advisory Opinion herein analyzed builds on a history of progressive decisions rendered by the ITLOS that gradually enhance the international legal framework relating to responsibility rules within the law of the sea.

\section{Concluding Remarks}

In short, the International Law of the Sea in this century still faces the dichotomy between freedom of navigation and controlled access, which embodies a traditional approach to maritime issues. This approach, in essence, divides the ocean into several jurisdictional spaces balancing the principle of sovereignty and the principle of freedom. Nonetheless, international legal scholarship and institutions have noticed the need for a more integrated approach, which is inspiring global and regional conventions and other soft law documents.

The mare liberum can no longer exist, for it was formulated for another era, another historic moment. If applied vigorously, as the (absolute) freedom of fishing, for instance, this principle might limit effective enforcement of regulations on problems that deeply affect the ocean, such as IUU fishing. The sovereignty perception of the oceans' resources cannot represent, on the other hand, a barrier to the application of an integrated approach to the management of fisheries.

The current legal framework regarding IUU fishing provides the foundation for implementing such a renewed approach. Indeed, not only hard law, as the UNCLOS III and the 1995 Straddling Fish Stocks Agreement, but also soft law, as the Voluntary Guidelines of 
FAO and the UN Resolution 61/105, provide a relatively fertile field upon which an integrated approach may be build. However, the work of international organizations and the International Tribunal for the Law of the Sea is indispensable for the interpretation and consequent consolidation of new perspectives on ocean governance schemes. The main goal of current and future efforts ought to be the limitation of human impact on ecological systems, while taking into account contemporary demands for national development and economic growth.

For those reasons, the ITLOS was asked to render an advisory opinion on the flag state responsibility for IUU fishing activities conducted within the EEZ of third states party to the UNCLOS III. At the first moment, the Tribunal engaged in a fructiferous line of reasoning, recognizing the existence of "due diligence" obligations falling upon flag states relating to IUU fishing. Shortly afterwards, however, it refused to accept the possibility of holding a flag state liable for wrongful acts of vessels flying their flag.

Overall, despite likely skepticism of the legal literature towards the advisory opinion, considering the historical supremacy of a sectorial approach to the LOS, the opinion instigates clearly positive outcomes. Based on the principle of "due diligence", the Tribunal has not only reinforced the interaction between the LOS and other regimes, such as the law of responsibility and the environmental law, but also nurtured the shift from a purely traditional towards an integrated approach to tackling oceanic issues as grave as the IUU fishing.

\section{References}

ALLOT, Philip. Mare nostrum: a new international Law of the Sea. In: ROTHWELL, Donald R. (Ed.). Law of the Sea. Cheltenham: Edward Edgar, 2013. p. 793-816.

BAIRD, Rachel J. Aspects of illegal, unreported and unregulated fishing in the Southern Ocean. Dordrecht: Springer, 2006.

BARROS-PLATIAU, Ana Flávia et al. Correndo para o mar no antropoceno: a complexidade da governança dos oceanos e a estratégia brasileira de gestão dos recursos marinhos. In: Varella, Marcelo D. Revista de Direito
Internacional, vol.12, no.1 (current edition).

CHIRCOP, A. E. Operationalizing Article 82 of the United Nations Convention on the Law of the Sea: a New Role for the International Seabed Authority? Ocean Yearbook, v. 18, 2004.

CHURCHILL, Robin. The European Union and the challenges of marine governance: from sectoral response to integrated policy? In: VIDAS, Davor; SCHEI, Peter Johan. The world ocean in globalization: climate change, sustainable fisheries, biodiversity, shipping, regional issues. Leide: Nijhoff, 2011. p. 395-436.

CHURCHILL, Robin. Uncertainties in International High Seas Fisheries Management. Fisheries Research, v. 37, 1998.

CORTEN, Olivier. Méthodologie du droit internationale public. Bruxelles: Editions de l'Université de Bruxelles, 2009.

OLIVEIRA, Carina Costa de. Comentário à Opinião Consultiva 21 do Tribunal Internacional para o Direito do Mar [02/04/2015] In: Varella, Marcelo D. Revista de Direito Internacional, vol.12, no.1 (current edition).

OLIVEIRA, Carina Costa de, and MALJEAN-DUBOIS, Sandrine. Os limites dos termos bem público mundial, patrimônio comum da humanidade e bens comuns para delimitar as obrigações de preservação de recursos marinhos. In: Varella, Marcelo D. Revista de Direito Internacional, vol.12, no.1 (current edition).

CULLIS-SUZUKI, Sarika; DANIEL, Pauly. Failing the high seas: a global evaluation of regional fisheries management organizations. Marine Policy, 2010.

ENVIRONMENTAL JUSTICE FOUNDATION. Pirates and profiteers: how pirate fishing fleets are robbing people and oceans. London, 2005.

FOOD AND AGRICULTURE ORGANIZATION OF THE UNITED NATIONS. Code of Conduct for Responsible Fisheries. Rome: FAO, 1995.

FOOD AND AGRICULTURE ORGANIZATION OF THE UNITED NATIONS. Convention on the Law of the Sea. Montego Bay: FAO, 1982.

FOOD AND AGRICULTURE ORGANIZATION OF THE UNITED NATIONS. International Plan of Action to Prevent, Deter and Eliminate IUU Fishing. Rome: FAO, 2001. 
FOOD AND AGRICULTURE ORGANIZATION OF THE UNITED NATIONS. Pulp Mills on the River Uruguay case, Argentina v. Uruguay. Judgment, 2010, ICJ.

FOOD AND AGRICULTURE ORGANIZATION OF THE UNITED NATIONS. Report of the Expert Consultation on the Development of a Comprehensive Global Record of Fishing Vessels. Rome: FAO, 2008.

FOOD AND AGRICULTURE ORGANIZATION OF THE UNITED NATIONS. Review of the state of the world marine fisheries resources. Rome: FAO, 2014.

FOOD AND AGRICULTURE ORGANIZATION OF THE UNITED NATIONS. Rome Declaration on IUU Fishing. Rome: FAO, 2005.

FOOD AND AGRICULTURE ORGANIZATION OF THE UNITED NATIONS. Straddling Stock Fish Agreement. New York: FAO, 1995.

FOOD AND AGRICULTURE ORGANIZATION OF THE UNITED NATIONS. Voluntary Guidelines for Flag State Performance. Rome: FAO, 2014.

FREESTONE, David. Problems of high seas governance. In: VIDAS, Davor; SCHEI, Peter Johan. The world ocean in globalization: climate change, sustainable fisheries, biodiversity, shipping, regional issues. Leiden: Nijhoff, 2011. p. 99-132.

GALINDO, George Rodrigo Bandeira. Quem diz bumanidade pretende enganar?: internacionalistas os usos da noção de patrimônio comum da humanidade aplicada aos fundos marinhos (1967-1994). 2006. PhD (Dissertation). Brasilia: University of Brasília, 2006.

GOLITSYN, Vladimir. Major challenges of globalization for seas and oceans: legal aspects. In: VIDAS, Davor; SCHEI, Peter Johan. The world ocean in globalization: climate change, sustainable fisheries, biodiversity, shipping, regional issues. Leide: Nijhoff, 2011.

GROTIUS, Hugo. The Free Sea, trans. Richard Hakluyt, with William Welwod's Critique and Grotius's Reply, ed. David Armitage. Indianapolis: Liberty Fund, 2004. p. 95. Available at: <http://oll.libertyfund.org/ titles/859\#Grotius_0450_251>. Access on: 24. Mar. 2015.

INTERNATIONAL COURT OF JUSTICE. Fisheries Jurisdiction Case, United Kingdom v. Ireland, 1974.
INTERNATIONAL TRIBUNAL FOR THE LAW OF THE SEA. Advisory Opinion on the Request submitted to the Tribunal by the Sub-Regional Fisheries Commission. Hamburg, 2015.

INTERNATIONAL TRIBUNAL FOR THE LAW OF THE SEA. Advisory Opinion to the request of the International Seabed Authority regarding responsibilities and obligations of states sponsoring persons and entities with respect to activities in the Area. Hamburg, 2011.

JOHNSTON, Douglas M. The theory and history of ocean boundary making. Montreal: McGill-Queens University Press, 1988.

KIRCHNER, Andree. The Outer Continental Shelf: background and current developments. In: NDIAYE, Tafsir; WOLFRUM, Rüdiger. Law of the Sea, Environmental Law and Settlement of Disputes: Liber Amicorum Judge Thomas A. Mensah. Leiden: Nijhoff, 2007. p. 593- 611.

KRASKA, James. The lost dimension: food security and the South China Sea disputes. Harvard Law School National Security Journal, Online article, 2015. Availlable at: < http:/ / harvardnsj.org/2015/02/ the-lost-dimensionfood-security-and-the-south-china-sea-disputes/>. Access on: 29 Apr.2015.

LARSEN, Christina. China's illegal fishing expeditions threaten world's waters. Bloomberg Business. November 19, 2013. Available at: <http://www.bloomberg.com/bw/ articles/2013-11-19/china-s-illegal-fishing-expeditionsthreaten-world-waters >. Access on: 26 Apr. 2015.

LEEMANS, Eelco and RAMMELT, Thomas. Mare liberum or mare restrictum? Challenges for the Maritime Industry. In: VIDAS, Davor; SCHEI, Peter Johan. The world ocean in globalization: climate change, sustainable fisheries, biodiversity, shipping, regional issues. Leide: Nijhoff, 2011.

MCDORMAN, Ted L. et al. International Ocean Law: materials and commentaries. Durham: Carolina Academic Press, 2005.

MCDORMAN, Ted L. et al. The entry into force of the Law of the Sea Convention and South-East Asia: an introductory comment. In: MATICS, K. I.; MCDORMAN, T. (Ed.). Selected papers in commemoration of the entry into force of the U.N. Convention on the Law of the Sea. Bangkok: SEAPOL, 1995.

NORDQUIST, Myron; et al (Ed.). Freedom of navigation 
and globalization. Leiden: Nijhoff, 2015.

ODA, Shigeru. Fifty years of the Law of the Sea: with a special section on the International Court of Justice. The Hague: Kluwer Law International, 2003.

OETER, Stefan. Theorising the Global Legal Order: an Institutionalist Perspective. In: HALPIN, Andrew; ROEBEN, Volker (Ed.). Theorising the Global Legal Order. Hart: Oxford, 2009. p. 61-83.

OXMAN, Bernard. The territorial temptation: a siren song at sea. In: ROTHWELL, Donald R. (Ed.). Law of the Sea. Cheltenham: Edward Edgar, 2013. p. 3-24.

PIRTLE, Charles E. Military uses of ocean space and the law of the sea in the new millennium. Ocean Development and International Law, v. 31, n. 7, p. 11-32, 2000.

RANGEL, Vicente Marotta. Settlement of Disputes relating to the Delimitation of the Outer Continental Shelf: the role of International Courts and Arbitral Tribunals. In: ANUÁRIO BRASILEIRO DE DIREITO INTERNACIONAL, 11., 2007, Belo Horizonte: CEDIN, 2007. p. 232-247.

ROTHWELL, Donald R.; STEPHENS, Tim. Building on the strengths and addressing the challenges: the role of the Law of the Sea Institutions. Journal of Maritime Affairs, Philadelphia, v. 35, p. 131-156, 2004.

ROTHWELL, Donald R.; STEPHENS, Tim. The International Law of the Sea. Oxford: Hart, 2010.

SCELLE, George. Obssession du territoire. The Hague: Nijhoff, 1958.

SCHIMDT, Carl-Christian. Addressing Illegal, Unreported and Unregulated (IUU) Fishing. International Fisheries Compliance Conference, Brussels, 2004. Available at: <http://www.oecd.org/greengrowth/fisheries/34029751.pdf>. Access on: 29 Apr. 2015

SHAW, Malcolm. International Law. 6. ed. Cambridge: CUP, 2008.

SIMMA, Bruno; PAULUS, Andreas. The internatio- nal community: facing the challenges of globalization. EJIL, v. 9, n. 2, 1998.

SUB REGIONAL FISHERIES COMMISSION. Convention, Praia, Cabo Verde, 1985. Available at: <http:// www.spcsrp.org/medias/csrp/documents/CSRP1993-ConvPraya.PDF>. Access on: 25 Apr. 2015.

TANAKA, Yoshifumi. A Dual Approach to Ocean Governance: the cases of zonal and integrated management in International Law of the Sea. Paris: The Ashgate International Law Series, 2008.

TEUBNER, Gunther; FISCHER-LESCANO, Andreas. Regime Collisions: the vain search for legal unity in the fragmentation of global law. Michigan Journal of International Law, v. 25, n. 4, 2004.

TOMUSCHAT, Christian. International Law: ensuring the survival of mankind on the eve of a new century, RCADI, 1999.

VARGAS, Jorge A. Latin America and its contributions to the Law of the Sea. In: LAURSEN, Finn (Ed.). Towards a New International Marine Order. Leiden: Nijhoff, 1982.

VATTEL, Emmerich de. The Law of Nations: or principles of the law of nature applied to the conduct and affairs of nations and sovereigns. Philadelphia: Law Book Sellers, 1863.

VENTURA, Victor Alencar Mayer Feitosa. Ecologização do direito internacional humanitário: proteção ambiental em tempos de guerra. João Pessoa: UFPB, 2014.

VIDAS, Davor; SCHEI, Peter Johan (Ed.). The world ocean in globalization: climate change, sustainable fisheries, biodiversity, shipping regional issues. Leiden: Nijhoff, 2011.

WARNER, Robin. Protecting the oceans beyond national jurisdiction: strengthening the international law framework. Leiden: Nijhoff, 2009.

YOUNG, Margaret (Ed.). Regime interaction in International Law: facing fragmentation. Cambridge: CUP, 2012. 
Para publicar na Revista de Direito Internacional, acesse o endereço eletrônico www.rdi.uniceub.br ou www.brazilianjournal.org.

Observe as normas de publicação, para facilitar e agilizar o trabalho de edição. 